\title{
X-linked severe congenital neutropenia
}

INSERM

\section{Source}

INSERM. (1999). Orphanet: an online rare disease and orphan drug data base. $\underline{X \text {-linked }}$ severe congenital neutropenia. ORPHA:86788

X-linked severe congenital neutropenia is an immunodeficiency syndrome characterized by recurrent major bacterial infections, severe cong enital neutropenia, and monocytopenia. It has been described in five males spanning three generations of one family. It is transmitted as an X-linked recessive trait and is caused by mutations in the WAS gene, encoding the WASP protein. 